\title{
Theoretical Framework Of The Factors Affecting University Academics' Job Satisfaction
}

\author{
Sujit Kumar Basak, Durban University of Technology, South Africa
}

Dr. D.W. Govender, University of KwaZulu-Natal, South Africa

\begin{abstract}
This paper aims to present a theoretical framework of the factors affecting university academics' job satisfaction, which is achieved by identifying the contributing factors. The main objective of the research was concluded in designing a theoretical framework based on the existing literature. The novelty of this paper is the use of a significant body of literature focused on the existing literature about the factors affecting university academics' job satisfaction, which was used to achieve the aim in designing the framework. The findings could assist in creating an awareness of the factors incorporated at tertiary institutions that contribute to university academics' job satisfaction.
\end{abstract}

Keywords: Satisfaction; Factors; Academics; University; Framework

\section{INTRODUCTION}

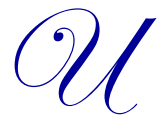

niversities are considered as the highest source of knowledge and as awareness production institutions, in addition to where manpower is trained in different fields of life (Khalid et al., 2012). In higher education, a positive and healthy climate is needed for university faculty job satisfaction. A positive climate can increase a university academics' satisfaction with their occupation through the inclusion of a variety of factors, such as healthy working conditions, relationships with colleagues, support of research and teaching, appropriate salary, promotion opportunities, etc. Furthermore, this also increases the overall productivity that the educational institute fosters (Noordin \& Jusoff, 2009). Similarly, studies conducted by Santhapparaj and Alam (2005) and Baloch (2009) indicate that a positive climate at the university increases not only academic job satisfaction but also performance.

According to Davis (1981), satisfaction in a specific profession links with the employee when the features of the job and the desire to perform the work are matched to the employee. It is an attitude that is developed by an individual to the work and conditions of employment (Luthans, 1994). Çetinkanat (2000) highlights personal evaluation of occupational satisfaction, such as the position itself, attitude of the administrator or the results (pay, job security) of the employment. However, Jenaibi (2010) concludes that job satisfaction is an emotional state that can be evaluated by the workers' experiences or position and it is a state where an employee feels perfection in his/her work, value and worth of his/her work, and recognition.

\section{PROBLEM STATEMENT}

With a host of factors contributing to tertiary institution academics' job satisfaction, a significant body of literature was researched to design a framework indicating what all these factors are and how they affect job satisfaction levels.

According to Adeel et al. (2011), university academic job satisfaction levels are positively affected by the compensation or pay given to employees. Talat et al. (2012) indicate that low job satisfaction leads to higher 
absenteeism (Vroom, 1964) and labour turnover rates (Clark et al., 1997). Amzat and Idris (2010) state that employees who receive low salaries usually cause serious upheavals, with regard to job satisfaction, across the world. According to Noordin and Jusoff (2009), salary, status, and age affect academic staff job satisfaction in Malaysian universities.

On the one hand, Ellickson and Longsdon (2001) reveal that in higher education, academic job satisfaction is affected by adequate equipment, required resources, training opportunities, and an equitable workload. Williams (1995) finds, on the other hand, that academic benefits strongly affect job satisfaction.

Studies by various researchers (Dinham \& Scott, 1998 and 2000; Scott and Dinham, 2003; Scot et al., 2001; van den Berg, 2002; Vandenberghe \& Huberman, 1999; Zembylas \& Papanastasiou, 2004) indicate one of the most important factors is that of salaries and it leads to low or high motivation and job satisfaction for academics in higher education. Souza-Poza and Souza-Poza (2000b) identify salary as the predictor for employees' satisfaction. However, Miller (1980) also states that rewards for employees have an effect on job satisfaction and better performance (Saba, 2011).

\section{RESEARCH QUESTION}

What are the important factors that affect university academics' job satisfaction?

\section{AIMS AND OBJECTIVES}

The aim of this study is to design a framework based on the factors affecting university academics' job satisfaction. This aim is achieved through the specific objective - to identify the factors affecting university academics' job satisfaction.

\section{LITERATURE REVIEW}

A study was conducted by Ghaffar et al. (2013) on 60 academic staff (lecturers, assistant professors, associate professors, and professors) and the findings indicate that security, promotion and co-workers are important factors for university academics' job satisfaction. Another study by Locke (1976) and Gracez (2006), cited in Ghaffar et al. (2013), indicates that job satisfaction is usually experienced by academics when they have proficiency, value, and recognition. Adeel et al. (2011) find a strong association between academic job satisfaction and promotion. Similarly, several studies have been conducted by many researchers, with the conclusion that there is a correlation between academic job satisfaction and several variables. These include achievement, recognition, the work itself, responsibility, advancement, policy and administration, supervision, salary, interpersonal relations, working conditions, age, tenure, educational level, teaching experience, job activities, and gender (Aebi, 1972; Berns, 1989; Cano, 1990; Cano \& Miller, 1992; Flowers \& Pepple, 1988; Herzberg et al., 1959; Kotrlik \& Malek, 1986; Morris, 1972; Tenney, 1985).

Findings from research done by Khalid et al. (2012) indicate that a positive and healthy university structure increases the university academics' job satisfaction. Furthermore, Khalid et al. (2012) also show that it not only increases job satisfaction but, at the same time, improves the learning environment as well as increases university productivity. However, their study concludes that private university academics are more satisfied in terms of pay, supervision, and promotional opportunities, compared to public universities, while public university academics are more satisfied in terms of co-workers' behaviour and job security.

A study by Sokoya (2000) finds that the set of job satisfaction predictors includes pay, work, promotion, supervision, environment, and co-workers. Another study by Decenzo and Robbins (1998) concludes that job satisfaction factors of any officers or any employees include pay, work, co-workers, and environment. Studies by DeVane and Sandy (2003) indicate that job satisfaction of employees or workers is measured in attitude to the job, relations with co-workers, supervision, company policy and support, promotion, and pay. 
Results from Luthans (2005) show that pay, promotion, work, supervision and fellow workers are the main factors for the university academic, in terms of job satisfaction. Studies conducted by Testa (1999), Pearson and Seiler (1983), and Kline and Boyd (1991) reveal that job satisfaction includes compensation, opportunity for advancement, leadership style, work environment, organizational structure and climate. In Malaysia, Santhapparaj and Alam (2005) conducted a study and found that private university academics' job satisfaction include salary, promotion, fringe benefits, and working conditions.

In the United Kingdom (UK), a study was conducted by Oshagbemi (2003), which indicates that job rank level and occupational level are the factors that are usually considered as contributing to job satisfaction. Research conducted by Al-Rubaish et al. (2011) delivered a response rate of 72.9 percent and the results show that job satisfaction factors include authority, supervision, policies and facilities, the work itself, interpersonal relationships, commitment, salary and workload. Similarly, another study by Saygi et al. (2011) finds that job satisfaction factors are co-workers and working as a team, while sharing also rated as important. Studies from Saba and Zafar (2013) reveal that appropriate compensation, equivalent promotion opportunities, job security, suitable working conditions and the work itself have an impact on public and private university academics' job satisfaction in Pakistan.

Souza-Poza and Souza-Poza (2000a) and Miller (1980) maintain that job satisfaction was highest among employees who received the most reward. Another study at a Massachusetts higher education institution, conducted by Grace and Khalsa (2003), concludes that professional development and salary package are the most important job satisfaction factors. However, the relationship behaviour of supervisory staff has an effect on academic job satisfaction (Graham \& Messner, 1998). Furthermore, Bassett's (1994) study also indicates that supervisors can increase the employees' job satisfaction. Similarly, results from Ellickson and Longsdon (2001) conclude that promotional opportunities have a positive impact on the employees' job satisfaction. Research by Berta (2005) finds that positive relationships with fellow workers increase with the job satisfaction. Similar findings by Ting (1997) support the findings that relationships with co-workers are improved when employees experience job satisfaction.

According to Arnold and Feldman (1996:86-89), pay has a positive impact in determining job satisfaction. The study further reveals that promotion also influences job satisfaction, when compared to recognition, and achievement. Findings from research done by Baron and Greenberg (2003) indicate that when employees observe that their supervisors are fair, competent, and sincere, their level of job satisfaction increases. Results from a study done by Robbins (2002) indicate that the working environment increases employees' job satisfaction very positively. In a study by Danish and Usman (2010), it is concluded that rewards increase and decrease the satisfaction of employees.

Santhapparaj and Alam (2005) conducted a study in Malaysia on 173 academics of a private university. The results show that there is a relation between pay, promotion, fringe benefits, working conditions, support for research, support of teaching, and gender. Furthermore, they also indicate that pay, promotion, working conditions and support of research have a positive and significant effect on the university academics' job satisfaction. According to Oshagbemi (1997), Oshagbemi (1999), Oshagbemi (2000), Fields and Blum (1997), Mueller and Wallace (1996), and Klecker and Loadman (1999), an employee's job satisfaction usually depends on the individual's personal characteristics and characteristics of the job itself. However, age, gender, education status, hours of work, and the earning figure are the factors that affect university academics' job satisfaction.

Siddiqui and Saba (2013) show that job security affects university academics' job satisfaction while fringe benefits have a low affect. Souza-Poza and Souza-Poza (2000a) identify that an employee's salary is a forecaster of job satisfaction. Furthermore, in his studies, Miller (1980) finds that employees who are better rewarded experience better job satisfaction.

\section{METHODOLOGY}

The objective introduced in this paper is to identify the main factors that affect university academics' job satisfaction. The identification was drawn from existing literature and the results of this paper were drawn by compiling job satisfaction factors affecting university academics. A systematic literature review was done based on the following steps: formulation of the review question, devising the search strategy, application of the study selection criteria, study design, and the quality appraisal (Croucher et al., 2003). 


\section{Formulate The Review Question}

Formulation of the review question was identified by means of a systematic review that provides the focus and boundaries and shapes all aspects of the review process - inclusion and exclusion criteria, the search strategy, amount of literature reviewed, the quality appraisal, and the synthesis of evidence (Wallace et al., 2005). The review question was guided by the following question: "What are the factors affecting university academics" job satisfaction?"

\section{Devising The Search Strategy}

The search strategy was comprehensive and related to the review question, including factors affecting university academics' job satisfaction, job satisfaction by university academics, etc.

\section{Application Of Study Selection Criteria}

Before research studies are entered into systematic review, they are subjected to two filters. The first filter comprises a set of inclusion and exclusion criteria, and only when the research is considered relevant and able to address the review question, is it taken through to the second filter (Wallace et al., 2005).

\section{Study Design}

This study includes empirical evidence from experimental or observational research, which includes qualitative research. The study also includes unpublished or published work (Wallace et al., 2005). In this article, only those studies directly associated with factors affecting university academics' job satisfaction were selected.

\section{The Quality Appraisal Criteria}

The research met all five necessary elements of quality appraisal criteria (Wallace et al., 2005; source: Croucher et al., 2003) for validity and trustworthy findings. Articles were selected which were significant, acceptable, reliable and empirically valid. Furthermore, each study had good research questions and theory, along with a model or theoretical framework.

The Results section developed from the existing literature and presented in Figure 1. 


\section{RESULTS}

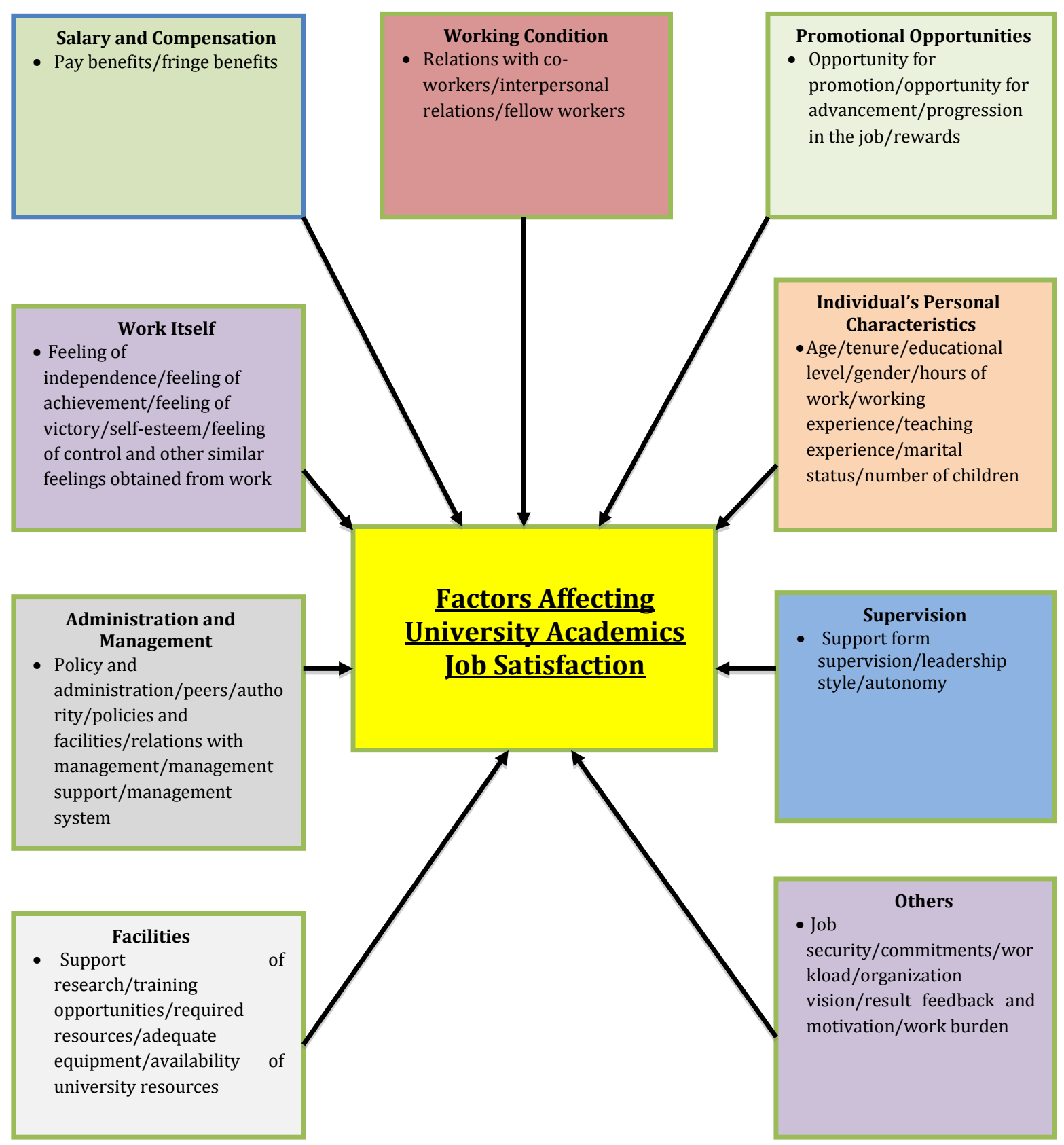

Figure 1: A Proposed Framework On Factors Affecting University Academics' Job Satisfaction

The above framework clearly shows that the following factors contribute to university academics' job satisfaction: salary and compensation (pay benefits/fringe benefits), working conditions (relations with coworkers/interpersonal relations/fellow workers), promotional opportunities (opportunity for promotion/opportunity for advancement/progression in the job/rewards), work itself (feeling of independence/feeling of achievement/feeling of victory/self-esteem/feeling of control and other similar feelings obtained from work), individual's personal characteristics (Age/tenure/educational level/gender/hours of work/working experience/teaching experience/marital status/number of children), administration and management (Policy and 
administration/peers/authority/policies and facilities/relations with management/management support/management), supervision (Support form supervision/leadership style/autonomy), facilities (Support of research/training opportunities/required resources/adequate equipment/availability of university resources), and others (Job security/commitments/workload/organization vision/result feedback and motivation/work burden).

\section{CONCLUSION AND RECOMMENDATIONS}

This study identified all factors that affect university academics' job satisfaction. It also provided useful information for university academics, in terms of job satisfaction. The study furthermore set out a "proposed framework based on factors affecting university academics job satisfaction, using the factors identified through various research studies, as a reference point. This includes Herzberg's (1966) Duality Theory of Job Satisfaction for the characteristics that include company policy and administration, relationship with supervisor, work environment, supervision, pay, relationships with peers, personal life, relationships with subordinates, status, security and so on. Regardless of which theory is followed, work itself, salary and compensation, job security, working conditions, promotional opportunities, supervision, administration and management, individual's personal characteristics, facilities, commitments, workloads, and others appear to be important factors to university academic job satisfaction and have been identified as the key factors affecting academic job satisfaction. In knowing what factors affect job satisfaction, it was possible to design a framework based on those needs.

Lastly, this study recommends that university academics should endeavour to know the factors that contribute to job satisfaction. This will help university academics to better understand and more easily achieve academic job satisfaction.

\section{AUTHOR INFORMATION}

Sujit Kumar Basak is a lecturer in the Department of Information Technology, Durban University of Technology, Durban, KwaZulu-Natal, South Africa. He is currently pursuing his Doctorate Degree in Information Technology (IT) at the Durban University of Technology. His research interests are algorithms, IT education, and health informatics. E-mail: sujitbasakmca@gmail.com.

Desmond Wesley Govender is a senior lecturer in the Department of Computer Science Education, University of KwaZulu-Natal, South Africa. He is currently the Discipline Leader of Computer Science Education and his research interests are technology integration in teaching and learning, programming paradigms, use of learning management systems to support learning. E-mail: govenderd50@ukzn.ac.za

\section{REFERENCES}

Adeel, M., Khan, I., Danial, A. H., \& Ahmad, B. (2011). Impact of HR practices on job satisfaction of university teacher: evidence from universities in Pakistan. Industrial Engineering Letters, 1(3), 10-17.

Aebi, C. J. (1972). The application of Herzberg's motivation-hygiene theory to college educators as tested by two different methodologies. Dissertation abstracts international, 3979-A.

Al-Rubaish, A. M., Rahim, S. A., Abumadini, M. S., \& Wosornu L. (2011). Academic job satisfaction questionnaire: Construction and validation in Saudi Arabia. Journal of Family Community Medicine, 8:1-7.

Amzat, I. H., \& Idris, D. A. R. (2010). Structural equation models of management and decision-making styles with job satisfaction of academic staff in Malaysian Research University. International Journal of Educational Management, 26(7), 616-645.

Arnold, H. J., \& Feldman, D. C. (1996). Organizational behavior. McGraw Hill.

Baloch, Q. B. (2009). Effects of job satisfaction on employees motivation and turn overintentions. Journal of Managerial Sciences, 2(1), 1-21.

Baron, A. R., \& Greenberg. (2003). Organisational behaviour in organisation: understanding and managing the human side of work. Canada: Prentice Hall.

Bassett, G. (1994). The case against job satisfaction. Business Horizons, 37 (3), 67. http://dx.doi.org/10.1016/00076813(94)90007-8.

Berns, R. G. (1989). Job satisfaction of vocational education teachers in Northwest Ohio. Bowling Green, OH. 
Bowling Green State University, Northwest Ohio Vocational Education Personnel Development Regional Center.

Berta, D. (2005). Put on a happy face: high morale can lift productivity. Nation's Restaurant News, 39 (20), 8.

Cano, J. (1990). Job satisfaction of teachers of agriculture. Proceedings of the $17^{\text {th }}$ National Agriculture Education Research Meeting. Cincinnati, Ohio, 115-120.

Cano, J., \& Miller, G. (1992). A gender analysis of job satisfaction, job satisfier factors, and job satisfaction, job satisfier factors, and job dissatisfier factors of agricultural education teachers. Journal of Agricultural Education, 33(3), 40-46.

Çetinkanat, C. (2000). Motivation and job satisfaction in organizations. Ankara: An1 Publication.

Clark, A. E., Georgellis, Y., \& Sanfey, P. (1997). Job satisfaction, wage changes and quits: evidence from Germany, Discussion paper No. 97/11, University of Kent at Canterbury.

Croucher, K., Quilgars, A., Wallace, A., Baldwin, S., \& Mather. L. (2003). Paying the portage. A systematic literature review of safety nets for home owners, York: Department of social policy and work.

Danish, R., \& Usman, A. (2010). Impact of reward and recognition on job satisfaction and motivation: an empirical study from Pakistan. International Journal of Business and Management, 5(2), 159-167.

Davis, K. (1981). Human behavior at work, Organization Behaviour, New York: McGraw-Hill.

Decenzo, D. A., \& Robbins, S. P. (1998). Personnel/Human resource management, ( $3^{\text {rd }}$ Ed.). Hall of India private limited New Delhi-Asoka K. Ghosh, Prentice.

DeVane, S. A., \& Sandy, Z. (2003). Job satisfaction of recent graduates in financial services, Chen Pirdu University US Department of Labor, Bureau of statistics, Available at: www.bls.gov.

Dinham, S., \& Scott, C. (1998). A three domain model of teacher and school executive satisfaction. Journal of Educational Administration, 36, 362-78.

Dinham, S., \& Scott, C. $(2000)$. Moving into the third, outer domain of teacher satisfaction. Journal of Educational Administration, 38, 378-396.

Ellickson, M. C., \& Longsdon, K. (2001). Determinants of job satisfaction of municipal government employees. Public Personnel Management, 31(3), 343-358.

Fields, D., \& Blum, T. (1997). Employee satisfaction in work groups with different gender composition. Journal of Organizational Behavior, 18, 181-196.

Flowers, J., \& Pepple, J. D. (1988). Assessment of the morale of beginning vocational agriculture teachers in Illinois. Journal of the American Association of Teacher Educators in Agriculture, 29(2), 2-6, 13.

Ghaffar, A., Ameer, B., Arshad, N., \& Urooj, F. (2013). Factors affecting job satisfaction level of academic staff in Pakistan. Journal of Education and practice 4(6).

Grace, D. H., \& Khalsa, S. A. (2003). Re-recruiting faculty and staff: the antidote to today's high attrition. Independent School, 62(3), 20-27.

Gracez, C. (2006). Job satisfaction: the challenges transformed organizations face. Miscellaneous. Retrieved March 13, 2010, from http://aplawrence.com/Misc/job satisfaction.html cited in Ghaffar, A. Ameer, B. Arshad, N. Urooj, F. (2013). Factors Affecting Job Satisfaction Level of Academic Staff in Pakistan, Journal of Education and Practice, 4(6).

Graham, M. W., \& Messner, P. E. (1998). Principals and job satisfaction [Electronic Version]. The International Journal of Educational Management, 12(5), 196-202.

Herzberg, F. (1966). Work and the nature of man, World Pub. Co, Cleveland.

Herzberg, F., Mausner, B., \& Snyderman, B. B. (1959). The motivation to work. New York: John Wiley \& Sons.

Jenaibi, B. A. L. (2010). Comparison among diverse public organizations in the UAE. Management Science and Engineering, 4(3), 60-79.

Khalid, S., Irshad, M. Z., \& Mahmood, B. (2012). Job satisfaction among academic staff: a comparative analysis between public and private sector universities of Punjab, Pakistan. International Journal of Business and Management, 7(1), 126-136.

Klecker, B., \& Loadman, W. (1999). Male elementary school teachers' ratings of job satisfaction by years of teaching experience, Education, 119, 504-513.

Kline, T. J. B., \& Boyd, J. E. (1991). Organizational structure, context, and climate: their relationships to job satisfaction at three managerial levels. Journal of General Psychology, 118(4), 305-316.

Kotrlik, J. W., \& Malek, A. P. (1986). Job satisfaction of vocational agriculture teachers in the Southeastern United States. Journal of the American Association of Teacher Educators in Agriculture, 27(1), 33-38.

Locke, E. A. (1976). The nature and causes of job satisfaction. In M.D. Dunnette (Ed.), Handbook of Industrial and 
Organizational Psychology, Chicago: Rand McNally, 1297-1349.

Luthans, F. (1994). Organizational Behaviour. New York: McGraw-Hill.

Luthans, F. (2005). Organizational Behaviour. McGraw-Hills International Edition.

Miller, J. (1980). Individual and Occupational Determinants of Job Satisfaction, Work and Occupations, 337-366.

Morris, J. (1972). Factors influencing job satisfaction/dissatisfaction among faculty in selected private Liberalarts Colleges. Dissertation Abtracts International, 3211-A.

Mueller, C., \& Wallace, J. (1996). Justice and the paradox of the contented female worker. Social Psychology Quarterly, 59, 338-349.

Noordin, F., \& Josuff, K. (2009). Levels of job satisfaction amongst Malaysian academic staff. Asian Social Science, $5(5)$.

Oshagbemi, T. (1997). The influence of rank on the job satisfaction of organizational members. Journal of Managerial Psychology, 12, 511-519.

Oshagbemi, T. (1999). Academics and their managers: a comparative study in job satisfaction. Personnel Review, $28,108-123$.

Oshagbemi, T. (2000). Correlates of pay satisfaction in higher education. The International Journal of Educational Management, 14, 31-39.

Oshagbemi, T. (2003). Personal correlates of job satisfaction: empirical evidence from UK universities. International Journal of Social Economics, 30(12).

Pearson, D. A., \& Seiler, R. E. (1983). Environmental satisfiers in academe. Higher Education, 12, 35-47.

Robbins, S. P. (2002). Orgainsational behaviour. New Jersey. Prentice Hall.

Saba, I. (2011). Measuring the job satisfaction level of the academic staff in Bahawalpur Colleges. International Journal of Academic Research in Business and Social Sciences, 1(1).

Saba, I., \& Zafar, O. (2013). Analyzing job satisfaction level of the academic staff: a case study of public and private universities of Punjab, Pakistan. International SAMANM Journal of Marketing and Management, $1(2)$.

Santhapparaj, A. S., \& Alam, S.S. (2005). Job satisfaction among academic staff in private universities in Malaysia. Journal of Social Sciences, 1(2), 72-76.

Saygi, H., Tolon, T., \& Tekogul, H. (2011). Job satisfaction among academic staff in fisheries faculties at Turkish universities. Social Behaviour and Personality, 39(10), 1395-1402.

Scott, C., \& Dinham, S. (2003). The development of scales to measure teacher and school executive occupational satisfaction. Journal of Educational Administration, 41, 74-86.

Scott, C., Stone, B., \& Dinham, S. (2001). 'I love teaching but...'international patterns of discontent. Education Policy Analysis Archives, 9(28), available at: http:epaa.asu.edu/epaa/v9n28.html.

Siddiqui, A., Saba, I. (2013). Determining the job satisfaction level of the academic staff at tertiary academic institutes of Pakistan. International Journal of Information, Business \& Management, 5(3), 42.

Sokoya, S. K. (2000). Personal predictors of job satisfaction for the public sector manager: implications for management practice and development in a developing economy. Journal of Business in Developing Nations, 4(1).

Sousa-Poza, A., \& Sousa-Poza A. A. (2000a). Well-being at work: a cross-national analysis of the levels and determinants of job satisfaction. Journal of Socio-Economics, 29, 517-538.

Souza-Poza, A., \& Souza-Poza, A. A. (2000b). Taking another look at the gender/job satisfaction paradox, Kyklos $53,135-152$.

Talat, I., Zulifqar, A., Ishfaq, A., Ashfaq, A., Muhammad, S., \& Saher Khushi, M. (2012). Does compensation and demographical variable influence on teachers commitment and job satisfaction? a study of university of the Punjab, Pakistan. International Journal of Business and Management, 7(4), 35-43.

Tenney, R. W. (1985). Factors affecting job satisfaction: cornell graduates (1974-1982) in agricultural education. Paper Presented at the Eastern Regional AATEA Leadership and Research Conference in Agricultural Education, Easton, MD. (ERIC Document Reproduction Service No. ED 225 677).

Testa, M. R. (1999). Satisfaction with organizational vision, job satisfaction and service efforts: an empirical investigation. Leadership \& Organization Development Journal, 20(3), 154-161.

Ting, Y. (1997). Determinants of job satisfaction of federal government employees. Public Personnel Management, 26(3), 313-334.

van den Berg, R. (2002). Teachers' meanings regarding educational practice. Review of Educational Research, 72, 577-625. 
Vandenberghe, R., \& Huberman, A. M. (1999), Understanding and preventing teacher burnout, Cambridge University Press, Cambridge.

Vroom, V. (1964). Work and motivation. Wiley: New York.

Wallace, A., Bevan, M., Croucher, K., Jackson, K., O’Malley, L., \& Orton, V. (2005). The impact of empty, second and holiday homes on the sustainability of rural communities-a systematic literature review. The centre for housing policy, The University of York, 1-142.

Williams, M. L. (1995). Antecedents of employee benefit level satisfaction: a test of a model. Journal of Management, 21, 1097-128.

Zembylas, M., \& Papanastasiou, E. (2004). Job satisfaction among school teachers in Cyprus. Journal of Educational Administration, 42, 357-374. 


\section{NOTES}

